\title{
Changes in population density of the urban population in southern Poland in the period 1950-2011 against the background of political and economic transformation
}

\begin{abstract}
This paper presents the changes in urban population density in the twentieth and twenty-first centuries in an area of approximately $20,000 \mathrm{~km}^{2}$ in southern Poland, which includes close to 100 towns and cities with a population of almost 4.5 million (in 2011) and an urbanisation index over $70 \%$. It is the most urbanised part of Poland and includes the Cracow agglomeration and the Upper Silesian conurbation. The analysis was performed using one of the statistical methods for estimating discrete distributions, the kernel function method. The conclusions served as a basis for the presentation of changes occurring in this area against the backdrop of political and economic transformation in Poland, as well as a scientific discussion concerning the state and future of the merging of these agglomerations in the light of the factors discussed.
\end{abstract}

Keywords

Cracow $\cdot$ Silesia $\cdot$ population density $\cdot$ political transformation $\cdot$ Kernel function

๑) University of Warsaw - Faculty of Geography and Regional Studies

\author{
Iwona Jażdżewska \\ Institute of Urban Geography and Tourism \\ Faculty of Geographical Sciences, \\ University of Łódż, Poland \\ e-mail: iwona.jazdzewsk@@uni.lodz.pl \\ Received: 1 July 2016 \\ Accepted: 20 July 2017
}

Introduction

Upper Silesia, covering the Dąbrowa Basin and the Cracow agglomeration, ${ }^{1}$ was the region with the highest density of urban networks and the highest population in Poland in both 1950 and 2011. The region also had the highest number of large and medium-sized cities (Jażdżewska 2008). During the socialist period, several investment projects were planned and carried out in the area, the biggest being the Lenin Foundry in Cracow, the Katowice Foundry, and numerous coal mines, power plants, chemical and automotive plants. They caused a large wave of migration of people from all over Poland to the cities in the region. Many migrants left their homes in the countryside when, similarly to the rest of Poland, the largest migration from rural to urban areas took place during the socialist era between 1945 and 1989. For several decades after World War II, the population of cities in the region grew due the high net migration and natural growth. In the period of Polish political transformation, the demographic processes changed, which resulted in numerous regional differences in population density. Issues related to population changes and demographic processes in the region have been addressed by many researchers. They mostly concerned Upper Silesia: Szajnowska-Wysocka (1995), Tkocz (2005), Krzysztofik and Runge (2010), Runge A. (2010). Runge, J. (2015), Rechlowicz and Tkocz (2013); Cracow: Zborowski (2005, 2011), Raźniak and Winiarczyk-Raźniak (2013); and all Polish cities: Eberhardt (1989), Korcelli (1996), Gawryszewski (2005), Jażdżewska (2008), Kałuża (2010) and Zborowski et al. (2012). In the aforementioned papers, the authors noted the processes

${ }^{1}$ The Cracow agglomeration is understood, as Parysek (2008:39) put it, as Cracow and its suburban centres (Bochnia, Krzeszowice, Myślenice, Skawina and Wieliczka). of depopulation of Upper Silesian cities and strong processes of suburbanisation around Cracow, as well as discussing their causes and the pace of change. They used various methods of research and presentation of results (tables, cartograms and cartodiagrams); only Jażdżewska (2008) used the kernel function to present population density changes for all Polish cities between 1939 and 2002.

This paper presents the results of the analysis of changes in urban population density in the most urbanised area of Poland. The analysis focuses primarily on changes occurring around the Cracow agglomeration and the Upper Silesian conurbation, as well as the area between them. The urban settlement network in the area in question is unusual in that there are several cities in the vicinity (within $25 \mathrm{~km}$, straight line distance) of each city. Thus, it can be claimed that it is internally coherent (Jażdżewska 2008).

The author believes that it helps to examine the changes in population density taking place across such a heavily industrialised area against the backdrop of economic and political transformations, and consider whether the areas could be merged.

\section{The study area and source data}

An area of Poland comprising $20,000 \mathrm{~km}^{2}$ was chosen for the analysis, where 99 towns and cities were located in 2011 with a total population of approximately 4.5 million, which includes two agglomerations: Cracow and Silesia (fig.1). After 1945, this area was part of Poland, while its western part belonged to Germany before the war. 
The study used data from the National Census in Poland, which was conducted in 1950, 1960, 1970, 1988, 2002 and 2011. GIS software was used to create numerical layers in the form of points, showing the network of cities with assigned number of inhabitants in the census year. The $20^{\text {th }}$ century saw changes not only in the number of residents, but also in the number of cities in Poland. New towns were created or combined with others, some were also stripped of their charters (Jażdżewska 2008), so each census had to take these changes into consideration in order to represent the actual number of cities.

\section{Methods of presenting population density}

Maps of population density are drawn in many ways, and their main task is to present this phenomenon in space as faithfully as possible. They are usually constructed using a cartogram, with quotients of population and spatial unit area presented in certain administrative units (municipalities, counties, provinces, etc.). If the analysis includes several census periods, and the administrative borders changed in the area under study, their visualisation and comparison requires additional work - the recalculation (estimation) of population in new administrative units. In the case of Poland, we are dealing with frequent changes in administrative boundaries at the state level: the number and areas of provinces changed fairly frequently after 1945 , counties were erased and formed, new municipalities were created, settlement units were swallowed by cities, while others turned into new cities. The cartogram method is 'sensitive' to changes in administrative borders, where population density is calculated. The cities under investigation also changed their administrative boundaries due to: the merging of cities (e.g. Bielsko and Biała), the inclusion of neighbouring villages or towns, as well as detachment from them and the emergence of new towns. Some of the cities have had varied histories - for example, Sławków, Radzionków and Wojkowice were incorporated into neighbouring cities, but after a dozen or so years they again became independent. These administrative changes should not have any impact on the results of mergers or detachments. In the case of the incorporation of rural areas into cities, a population increase can be observed, which in turn causes a rise in population density in these cities. For this reason, the cartogram method was abandoned and another method of presentation was chosen, namely kernel function.

\section{Kernel estimation method}

The kernel function was used to estimate city and population density. Its application eliminates the problems associated with cross-sectional studies comparing results from different periods with changes in the administrative division (Longley P.A. et al. 2005, Silverman 1981). The results shown on the map are not dependent on administrative boundaries, but only on the number of points and their associated weights, as well as the values of parameters used in the method.

The kernel estimation method (kernel function) uses a set of points in space. In this paper, cities were represented by points with one of the attributes being population. This means that data was represented by discrete objects, thus meeting the conditions of the method. For this type of data, density is not estimated by interpolation but by estimating density distribution. This is a nonparametric method associated with the so-called kernel estimators (kernel function). This function takes the following form:

$$
f_{h}^{\wedge}(x)=\frac{1}{n h} \sum_{i=1}^{n} K\left(\frac{x-x_{i}}{h}\right)
$$

where $n$ means sample size, $h$ is the smoothing coefficient (bandwidth), and $x_{1}, x_{2}, \ldots, x_{n}$ are points of the $n$-element random sample (Peters 2011). $K$ represents kernel functions with certain

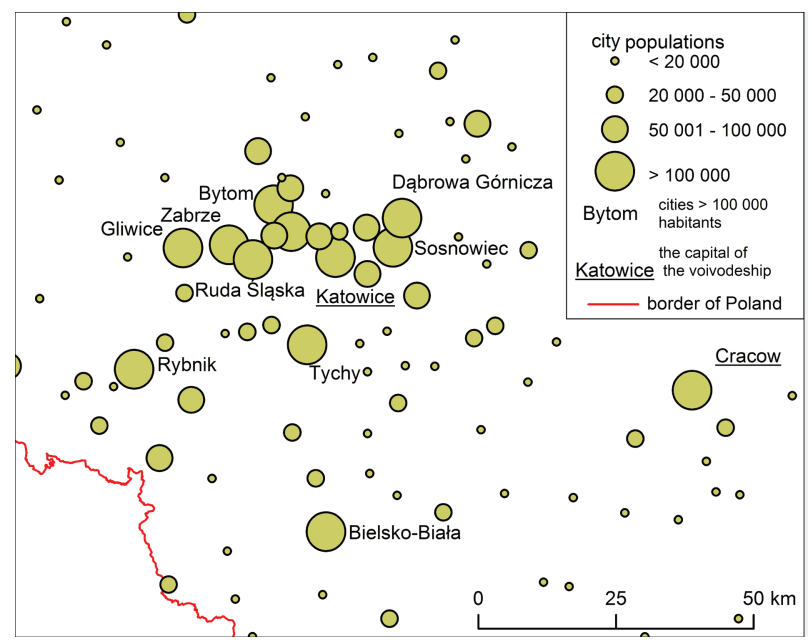

Figure 1. Area of study

Source: own elaboration

characteristics, including symmetry in relation to zero, integrated to 1. Usually, it takes the form of a Gaussian function:

$K(x)=\frac{1}{\sqrt{2 \pi}} \exp \left(\frac{-x^{2}}{2}\right)$

Probability density function depends primarily on the value of the parameter $h$, the smoothing coefficient. The higher its value, the greater the flattening (PA Longley et al. 2005 p. 344).

This method involves the initial creation of a grid of squares of a predetermined area (the length of its side is chosen subjectively and depends on the scale of the map and level of detail in results). ${ }^{2}$ Next, a circle of predetermined radius is drawn around each square and the number of settlement points within it is calculated. The key task is the selection of the correct radius length, as higher values may result in the excessive smoothing (generalisation) of results, while lower values result in excessive details. In this analysis of city densities, $r=50 \mathrm{~km}$ was chosen, with a square of $1 \mathrm{~km}$. In analysing population densities, $r=25 \mathrm{~km}$ and a square of $0.5 \mathrm{~km}$ were chosen. The band values were adopted after Jażdżewska (2008), who examined the population density changes for Polish cities between 1939 and 2002 and selected the $r$ values so that the results were comparable in several time periods and for different regions of Poland. Choosing the same parameters allows us to refer to Jażdżewska's results and gives the opportunity for further comparative research.

\section{Research results}

A series of maps presenting urban population density in census years 1950, 1960, 1970, 1988, 2002 and 2011 were analysed using density function estimation. Each of them presents the current number of cities in the census year and the estimated density of each city. The method was chosen deliberately, as it does not take into account the administrative divisions that occurred in Poland during the analysed period. The scales of the maps are identical, and the legend was made more uniform to make the maps comparable.

It should be noted that, between 1950 and 2011 in the studied area (fig. 1), the number of towns and cities increased from 64 in 1950 (1.98 million residents) to 99 in 2011 (4.5 million).

${ }^{2}$ This paper uses the ESRI ArcMap 9.2 software, Spatial Analysis module. 
In 1950, the biggest city was Cracow (almost 350,000), located in the eastern part of the area, which was by far the most populated city in this part of the region. Five other cities were located within $20 \mathrm{~km}$ of Cracow, but they did not exceed 100,000 residents (e.g. Wieliczka and Skawina). Here, the area of population concentration resembled uniform rings around Cracow (fig. 2).

On the other hand, in the western part of the study area covering Upper Silesia and the Dąbrowa Basin, there were as many as six cities over 100,000 residents (Katowice 175,000, Bytom 174,000, Zabrze 172,000, Chorzów 129,000, Gliwice 120,000 and Ruda Śląska 112,000), and three cities between 50,000 and 100,000(Sosnowiec 97,000, Świętochłowice and Bielsko 57,000 and Siemianowice Ślaskie 53,000 ), as well as 17 towns of 10,000 50,000 residents. The density of urban population is much higher than in the eastern part of the region, and its concentration resembles rings similar in shape to an ellipse with its long axis extending along the parallel $50^{\circ} \mathrm{N}$. About $50 \mathrm{~km}$ south of Katowice, within Cieszyn Silesia, was Bielsko with 50,000 inhabitants, surrounded by a small area of slightly higher urban population density.

During the socialist period, the Polish economy was centrally planned and the six-year plan instituted by the Parliament on 21 July 1950 included strong industrialisation and a 2.7-fold increase in investment expenses. During this time, more than $85 \%$ of the investments went into heavy industry. According to Karpinski (1979), the construction of 80 new industrial plants was initiated. ${ }^{3}$ The priority was the expansion of metallurgy, fuel and energy, machinery, chemical and construction materials. The next fiveyear plan adopted by the Parliament on 12 July 1957 included the continuation of the industrialisation policy, overcoming the disparities created in the previous years and the accelerated growth of living standards (Polska Ludowa 1965).

A large proportion of these investments happened in the area under study, including 'Ziemowit' coal mine in Lędziny and 'Lenin' in Mysłowice, the Jaworzno II power plant,the Lenin Foundry in Nowa Huta (Cracow), 'Oświęcim' chemical plant, 'Halemba' coal mine in Ruda Śląska, and Skawina power plant. The next stage of industrialisation was related to the further development of heavy industry - with the first mines created in the Rybnik Coal Area, production started in '1 Maja' mine in Wodzisław Śląski, 'Szczygłowice' in Knurów, 'Jastrzębie' in Jastrzębie Zdrój, as well as the power plants 'Siersza' in Trzebinia and 'Łagisza' in Będzin.

This intense industrialisation caused the influx of people to the cities. Poland also experienced a very high birth rate, described as a 'baby boom' (Rykiel, Jażdżewska 2002). In Krakow, the new workers' district of NowaHuta was planned, populated in large part by the employees of the Lenin Foundry. This resulted in an increase in population density in Cracow and the expansion of its concentration area, though it remained a monocentric agglomeration (fig. 3). The western part of Upper Silesia underwentgreater changes with population growing in a dozen cities and, interestingly, it was not Katowice but a group of cities to the west, especially Chorzów, that saw the largest population increase. The area with a high urban population density expanded significantly and was no longer as regular asten years before, with two arms clearly stretching out to the south and south-west. To the south, the city of Bielsko merged with Biała in 1951, while the villages of Czechowice and Dziedzice became the single mining city of Czechowice-Dziedzice. This resulted in a population increase in cities all over Cieszyn Silesia, with the future Bielsko agglomeration taking shape. Southwest of Katowice, the Rybnik Coal Area, one of the most urgent investments of the Communist government, began to form. New mining towns emerged nearby:

${ }^{3}$ Latuch M. (1970, p. 39) reports that 160 industrial companies were built during this time and over 180 were expanded.

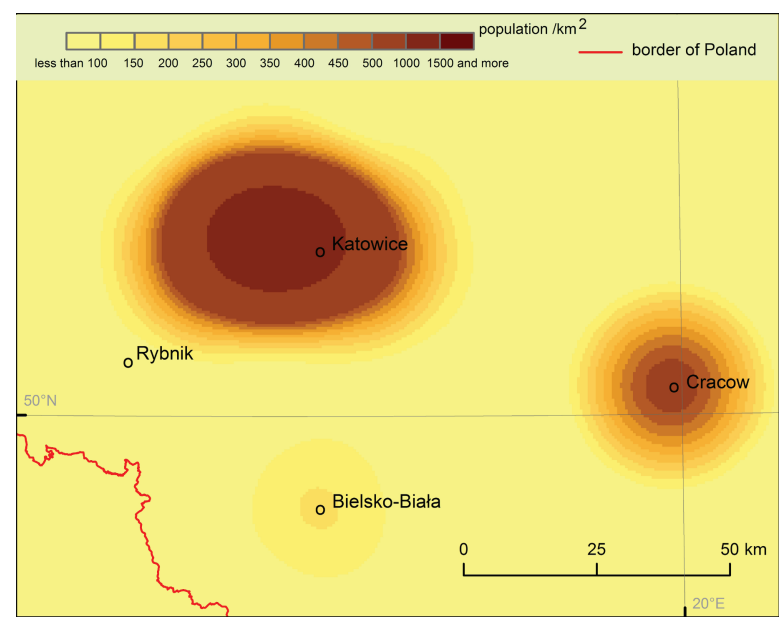

Figure 2. The density of urban population in 1950

Source: author's elaboration based on data from the Central Statistical Office

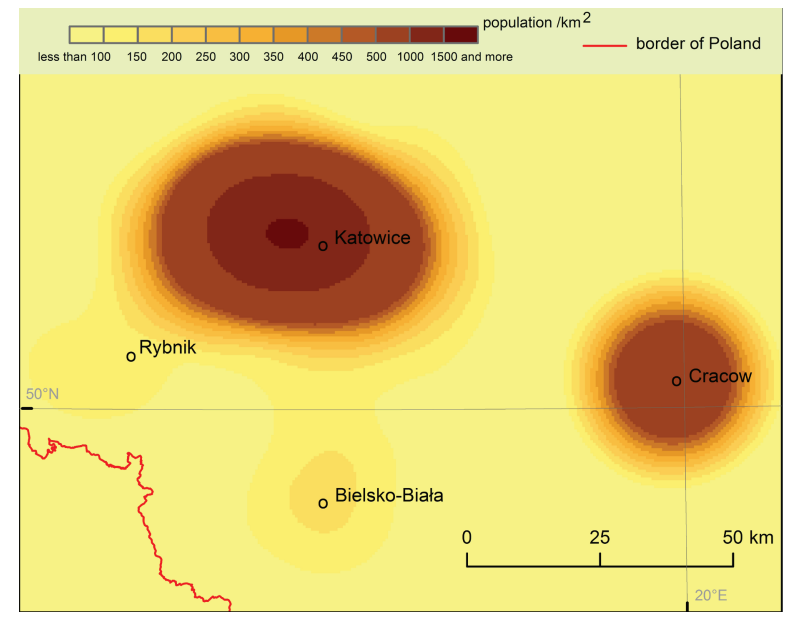

Figure 3. The density of urban population in 1960

Source: author's elaboration based on data from the Central Statistical Office

Rydułtowy (1951), Pszonów (1954) and Radlin (1954), which formed the south-western arm of increased population density. The Cracow and Silesia agglomerations were separated by a wide area of low urban population density (fig. 3).

Between 1965 and 1970, 'Moszczenica' and 'Manifest Lipcowy' mines in Jastrzębie-Zdrój, as well as the zinc foundry in Miasteczko Śląskie, started operation (Karpiński 1979). The Communist party authorities maintained their emphasis on heavy industrialisation, which caused massive migrations to cities and population growth, especially in the Silesian part of the area. A clear increase in population density can be seen in the central part, the core of the region between Sosnowiec to the east and Gliwice to the west. The development of mining towns in the south-western part of Upper Silesia led to an increase in their population, as shown on the density map (fig.4). In the Bielsko agglomeration, a growing population density occurred in the industrial cities of Czechowice-Dziedzice and Bielsko-Biała, while the southern arm of the region became more and more attached to its central part (fig.4). 


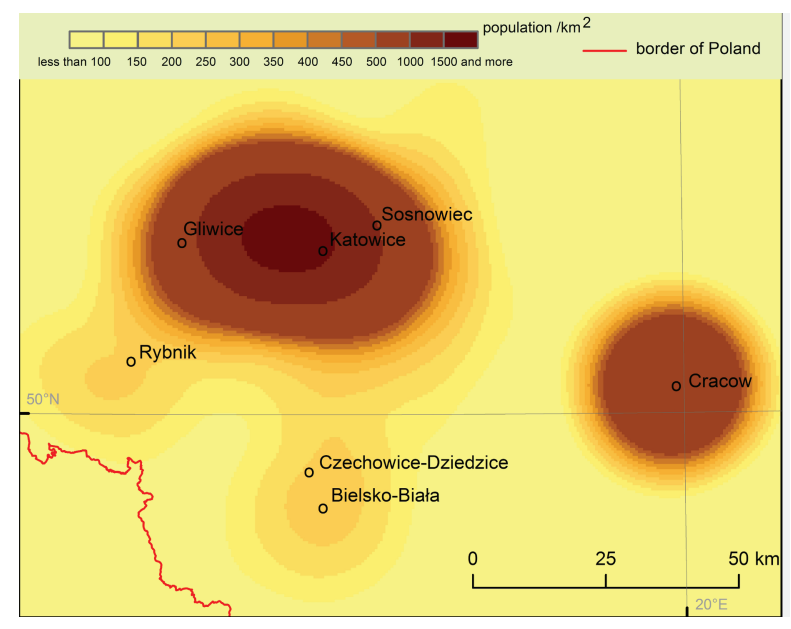

Figure 4. The density of urban population in 1970

Source: author's elaboration based on data from the Central Statistical Office

The first secretary of the Communist party, Edward Gierek, himself from Dabrowa Basin, called the seventies "the second industrialisation of Poland" (Karpiński 1979, p. 144). Unlike his predecessor, he took out loans to finance and modernise the Polish economy. A large portion of the investment was directed to Upper Silesia, for example, the 'Florian' foundry in Świętochłowice. This period was characterised by increasing investments in consumer industry, with one of the biggest projects in the area under study being the FSM Fiat 126p plant in Tychy and Bielsko-Biała (with loans and license from Italy). Thanks to a loan from France, the 'Katowice' foundry was constructed, which was twice as big as the Lenin Foundry in Cracow (Górniewicz 2005), as well as the steel mill in theLenin Foundry, 'Borynia' coal mine in Jastrzębie Zdrój, 'Śląsk coal mine in Ruda Śląska and 'XXXlecia PRL' coal mine in Pawłowice. It was the last period of economic growth in the People's Republic, which was ineffective under the socialist circumstances and slowly began to crumble. However, the launch of large investments resulted in a further influx of people to the industrial cities, leading to an increase in population density in these cities (fig. 5).

Other political decisions of the Communist government also influenced the cities and their size. Civic rights were given to new cities, such as the tourist city of Szczyrk (1973). In 1975 , the administrative division of Poland changed from 17 to 49 provinces. One of them was the Bielskie province, with its headquarters in Bielsko-Biała, where the population grew by $145.5 \%$ between 1975 and 1985 (with an increase of $108.1 \%$ in Cracow during the same decade).

The central part of Upper Silesia clearly expanded its high population density area, with two arms - the western one between Rybnik and Jastrzębie-Zdrój, and the Bielsko arm with the capital of the newly formed province - merging with the central area (fig.5).

The next decade, 1978-1988, saw the decline of Communism in Poland. Despite political hardships (martial law in 1981) and economic difficulties (wild hyperinflation reaching 600\%), the urban population kept growing. The directions in population density changes did not shift, but grew even stronger both in the centres and at the outskirts. The Rybnik Coal Area merged with the central part and the Bielsko subregion moved towards it (fig. 6).

In 1989, a political transformation happened in Poland, from a centrally planned economy to free-market capitalism. Poland

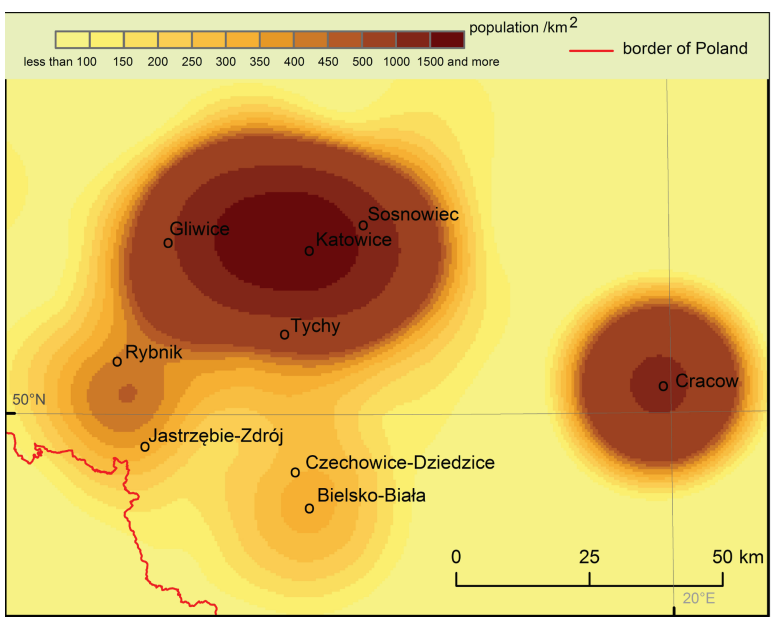

Figure 5. The density of urban population in 1978.

Source: author's elaboration based on data from the Central Statistical Office

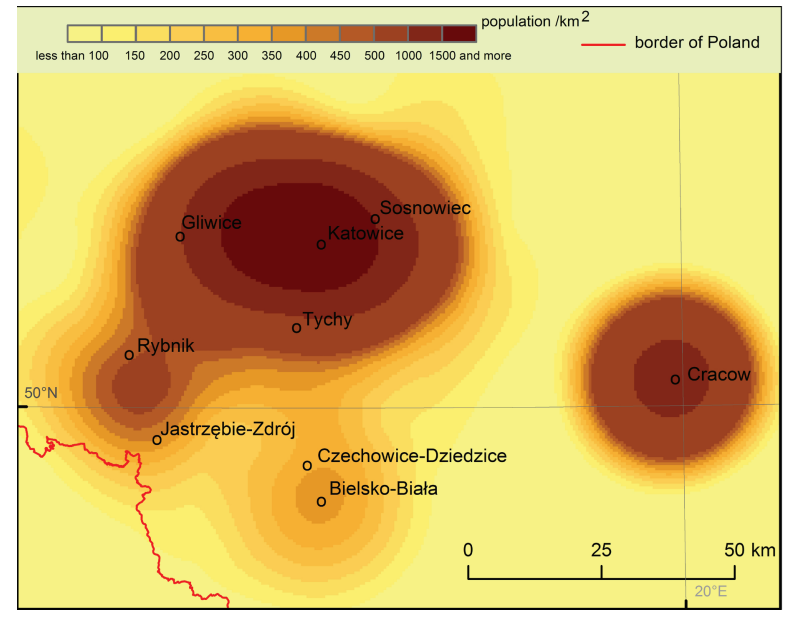

Figure 6. The density of urban population in 1988

Source: author's elaboration based on data from the Central Statistical Office

became a democratic country with a new system. Once again, the administrative division changed and the Bielskie province with its headquarters in Bielsko-Biała disappeared. The big industrial plants started to decline; meanwhile residents became dissatisfied with the quality of life and the environment in industrial cities. They started to move away from the biggest cities in Upper Silesia, which in turn caused the city density in the centre of the region to fall (fig. 7). The opposite phenomenon can be noted in the Bielsko subregion, where urban population grew year-byyear. Unlike Upper Silesia, Cracow kept attracting new residents. In the period 1988-2002, opposing trends in population density were noted between Upper Silesia and Cracow. As J. Runge (2015) writes, since 1993, Silesian cities have shown negative migration. Not a single city in the Katowice conurbation has experienced greater inflow than outflow. These cities became far less attractive than in previous years, especially in the 1970 s. This ended the centuries-long period dating back to the second half of the 18th century of the influence of migration influx on creating the local labour market and, in consequence, the population of the cities. The focus of population growth shifted 


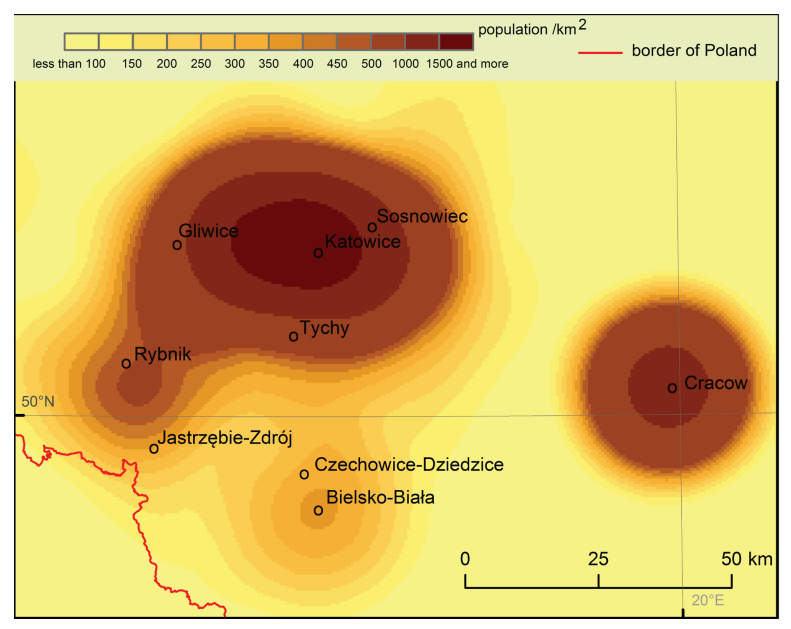

Figure 7. The density of urban population in 2002

Source: author's elaboration based on data from the Central Statistical Office

to the municipalities surrounding the Rybnik conurbation and the Bielsko-Biała agglomeration.

The collapse of many heavy industry plants resulted in less demand for employees in this sector of the economy that had dominated Upper Silesia. People ceased to flow into these cities in the numbers seen in previous decades and, after 2000 (according to CSO), migration in Upper Silesian cities shifted to negative values and steadily declined. Other sectors of the economy developed in this region, but not to an extent sufficient to encourage people in other regions to move to Upper Silesia. Most cities experienced a negative natural increase in the first decade of the 21st century (Zuzańska-Żyśko, 2003, 2005). City dwellers moved to suburban areas or the countryside. This negative rate of natural increase between 1989 and 2002 was observed in most cities of over 200,000 inhabitants in Poland, while the increase remained positive in less populous cities (Gawryszewski 2005:122).

Unlike Upper Silesia, Cracow saw positive migration and, from 2008, a positive natural increase as well, which resulted in the population of the city actually growing. It is also worth noting that after2000, Cracow experienced some of the largest absolute migration numbers among young people (20 to 29) of all Polish cities (Kałuża 2010)

These processes resulted in a decreasing population density in Upper Silesia and an increasing density in the Cracow area (fig.7). The area with the highest population density around Katowice, between Sosnowiec and Gliwice, is shrinking, while the area around Cracow is slightly expanding.

The analysis of changes in the density of the inflow of urban population in Upper Silesia, covering the Dąbrowa Basin and the Cracow agglomeration (fig.1-8), showed that the density was variable in time and geographical space. Despite its rapid acceleration over the whole region, the area between the two agglomerations is poorly urbanised and a clear boundary can be seen, which may stem from the medieval division between Silesia and Lesser Poland. There is no reason to believe that they could merge into one urbanised area any time soon.

Upper Silesia and the Dąbrowa Basin had the highest population density between 1950 and 2011, but it was not stable. The density increased during the socialist period, then fell rapidly (tab. 1). Unlike the Cracow agglomeration, the region 'spread out' in several directions, most intensely southwards, where two subregions, Rybnik and Bielsko, emerged (fig. 1-8)

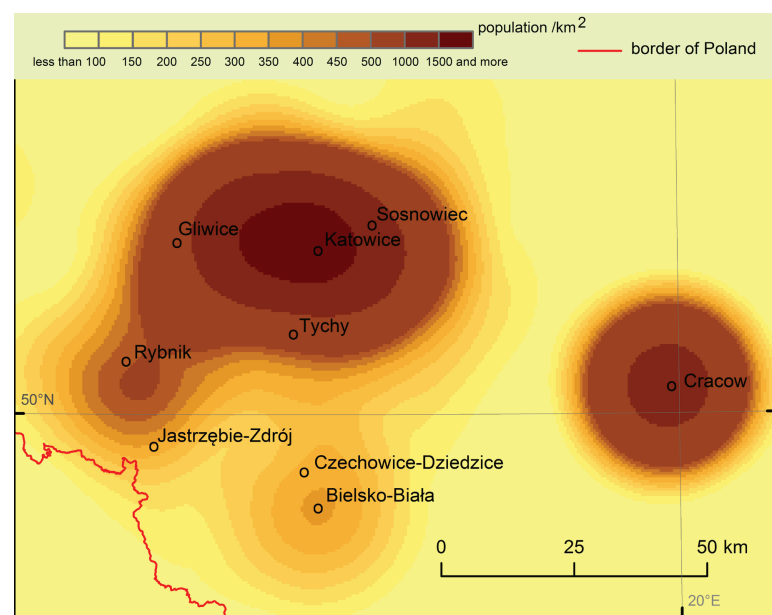

Figure 8. The density of urban population in 2011

Source: author's elaboration based on data from the Central Statistical Office

Table 1. The density of urban population in the Upper Silesian region in the period 1950-2011, by Kernel Method (estimated)

\begin{tabular}{|c|c|c|c|c|c|c|c|}
\hline $\begin{array}{c}\text { Population } \\
\text { density } / \\
\mathbf{k m}^{2}\end{array}$ & \multicolumn{7}{|c|}{ Total area $\left.\mathbf{( k m}^{2}\right)$ in each year } \\
\cline { 2 - 9 } & $\mathbf{1 9 5 0}$ & $\mathbf{1 9 6 0}$ & $\mathbf{1 9 7 0}$ & $\mathbf{1 9 7 8}$ & $\mathbf{1 9 8 8}$ & $\mathbf{2 0 0 2}$ & $\mathbf{2 0 1 1}$ \\
\hline $250-500$ & 683 & 761 & 894 & 2,127 & 2,314 & 2,325 & 2,334 \\
\hline $500-750$ & 425 & 463 & 501 & 559 & 721 & 718 & 709 \\
\hline $750-1,000$ & 313 & 343 & 368 & 390 & 410 & 429 & 433 \\
\hline $1,000-1,250$ & 253 & 271 & 282 & 312 & 320 & 335 & 339 \\
\hline $1,250-1,500$ & 159 & 234 & 236 & 256 & 267 & 278 & 279 \\
\hline$>1,500$ & - & 36 & 176 & 407 & 488 & 325 & 263 \\
\hline
\end{tabular}

Source: I. Jażdżewska based on CSO data

Table 2. The density of urban population in the Cracow agglomeration in the period 1950-2011, by Kernel Method (estimated)

\begin{tabular}{|c|c|c|c|c|c|c|c|}
\hline \multirow{2}{*}{$\begin{array}{c}\text { Population } \\
\text { Density } \\
/ \mathrm{km}^{2}\end{array}$} & \multicolumn{7}{|c|}{ Total area $\left(\mathbf{k m}^{2}\right)$ in each year } \\
\hline & 1950 & 1960 & 1970 & 1978 & 1988 & 2002 & 2011 \\
\hline $250-500$ & 570 & 483 & 442 & 412 & 400 & 401 & 404 \\
\hline $500-750$ & 77 & 368 & 335 & 309 & 300 & 299 & 299 \\
\hline $750-1,000$ & - & 14 & 205 & 258 & 250 & 250 & 247 \\
\hline $1,000-1,250$ & - & - & - & 92 & 163 & 179 & 186 \\
\hline
\end{tabular}

Source: I. Jażdżewska based on CSO data

The Cracow agglomeration saw a stable half century of population growth, owing to positive migration and natural increase, which led to a steady increase in population density (tab 2).

\section{Summary}

The changes that were occurring in the urbanised areas of Poland after 1945 were dynamic (Jażdżewska 2008), yet spatially diverse. The Upper Silesian conurbation located in southern Poland was the area with the highest urbanisation 
coefficient. Nearby, approximately $60 \mathrm{~km}$ to the east, is the Cracow agglomeration. During the period in question, Poland experienced numerous events that may have influenced the changes in urban population and, in consequence, the changes in population density. Most of them were the result of political decisions, as well as demographic processes and geographical circumstances (mineral deposits). The former include: political and economic transformation after World War II, investments in the development of heavy industry by the communist authorities,

planned new residential areas for workers (Nowa Huta, Nowe Tychy),

- administrative changes at the national level (new cities, administrative divisions), political and economic transformation in 1989,

- $\quad$ the slow decline of heavy industry.

The demographic processes were closely related: high birth rate, the 'baby boom' after World War II, migration from the countryside to the cities after World War II migrations related to the construction of new industrial plants, changes in the strength and direction of migration after 1990 ,

the processes of suburbanisation and counter-urbanisation in the 21 st century.

Over nearly 60 years, the growth of the urban population in the area from 1.8 to 4.5 million led to significant changes in the spatial disposition pattern as well as changes in population density. In 1950, the two regions - the Upper Silesian conurbation in the west and the Cracow agglomeration in the east - formed fairly regular areas. The western, elliptical one was bigger and more densely populated than the eastern one. From 1950 to 2011 the area of each region increased (fig. 2-8), but the process was not the same. The western region changed shape, 'spreading out' around the ellipse that formed the core of the Upper Silesian agglomeration, as well as to the south, where two arms emerged with Rybnik and Bielsko. On the other hand, the Cracow region remained monocentric and only expanded the circular area surrounding it.

The dynamics of urban population density increased in the area under study. The western region changed shape more rapidly; the density in its central part was higher than in the Cracow region throughout the whole period, but the tendency was not the same. After 1989, the density began to decrease significantly (fig. 6-8). On the other hand, the Cracow region experienced a visible increase in urban population density towards the end of this period.

The answer to the question of the regions merging into one depends on the scale on which the problem is discussed. From the national or European perspective, we can assume that they form a single area with increased urban population density, as the zone of around $60 \mathrm{~km}$ between them with lower density is not significant. However, this cannot be stated from the regional perspective. The boundary between them is clear and, which is worth stressing, historical, since it was the medieval border between Silesia and Cracow. If the process of depopulation in cities of the Upper Silesian conurbation continues, the vision of these two regions merging will be impossible.

\section{References}

Eberhardt, P 1989, 'Regiony wyludniające się w Polsce', Prace Geograficzne, vol. 148, IGiPZ PAN, Warszawa

Gawryszewski, A 2005, 'Ludność Polski w XX wieku', Monografie, vol. 5, IGiPZ PAN, Warszawa.

Górniewicz, G 2005, 'Międzynarodowe przepływy kapitału do 1980 r.' Roczniki Naukowe Wyższej Szkoły Bankowej w Toruniu, (4), pp. 115-125.

Jażdżewska, I 2008, 'Przemiany miejskiej sieci osadniczej w Polsce w świetle metod matematycznych', Łódź University Press, Łódź

Korcelli, P 1996, 'Aglomeracje miejskie w procesie transformacji - zarys problematyki', in Aglomeracje miejskie w procesie transformacji, IGiPZ, PAN, vol. 41, pp. 5-12.

Kałuża, D 2010, 'Migracje wewnętrzne a poziom rozwoju społeczno-gospodarczego wybranych największych miast w Polsce', Acta Universitatis Lodziensis. Folia Oeconomica, vol. 237, pp. 29-49.

Karpiński, A 1979, 'Industrializacja Polski i jej dotychczasowe etapy, in 35 lat gospodarki Polski Ludowej', ed K Secomski, PWE, Warszawa pp.129-151.

Krzysztofik, R \& Runge, J 2010, 'Urban shrinkage in Bytom and Sosnowiec, the Katowice Conurbation, Poland', Shrink Smart Research Report, University of Silesia, Sosnowiec.

Latuch, M1970, 'Migracje wewnętrzne w Polsce na tle industrializacji (1950-1960)', PWE Warszawa.

Longley, PA, Goodchild, MF, Magiure, DJ \& Rhind, DW 2005, 'Geographic Information Systems and Science', John Wiley \& Sons.

Parysek, JJ 2008, 'Aglomeracje w Polsce oraz problemy ich funkcjonowania i rozwoju', in Wybrane problemy rozwoju i rewitalizacji miast: aspekty poznawcze i praktyczne, ed JJ Parysek \& A Tölle, Biuletyn Geografii SpołecznoEkonomicznej i Gospodarki Przestrzennej, Seria Rozwój Regionalny i Polityka Regionalna, nr 5, pp.29-48, Bogucki Wydawnictwo Naukowe, Poznań.

Peters, S 2011, 'Interactive Scale-dependent multidimensional Point Data Selection Rusing enhanced Polarization Transformation', in Advances in Cartography and GIScience, ed. A Ruas, vol .1, pp. 387-409, Selection from ICC 2011 Paris, Springer, Heidelberg, Dordrecht, London, New York.

Polska Ludowa Słownik encyklopedyczny 1965, Wiedza Powszechna, Warszawa.

Rechlowicz, M \& Tkocz, M 2013, 'Depopulation of traditional mining regions in Central and East Europe: case study of the Uppersilesian Basin (Poland) and the Donetsk Basin (Ukraine)', European Scientific Journal, Special Edition, vol. 3, pp. 450-459.

Silverman, BV 1981, 'Using Kernel Density Estimates to Investigate Multimodality', Journal of the Royal Statistical Society, Series B (Methodological), vol. 43, issue 1, pp. 97-99.

Raźniak, P \& Winiarczyk-Raźniak, A 2013, 'Spatial distribution and differences in migration patterns and revenues of gminas in the Kraków Metropolitan Area', Bulletin of Geography. Socio-economic Series, vol. 19, issue 19, pp. 73-86.

Runge, A 2010, 'Procesy i struktury ludnościowe w województwie śląskim' in Procesy i struktury demograficzno-społeczne na obszarze województwa śląskiego w latach 19882008, Urząd Statystyczny w Katowicach, Katowice.

Runge, J 2015, 'Regionalne i lokalne konsekwencje współczesnych przemian demograficznych Polskim - elementy metodologii badań. Przykład województwa śląskiego', Studia Ekonomiczne, vol. 223, pp.279-289. 
Rykiel, Z \& Jażdżewska, I 2002, 'The maturing of the Polish urban system'; Chapter 11, in International Handbook of Urban Sytems, ed HS Geyer, pp. 271-294.

Szajnowska-Wysocka, A 1995, 'Podstawy zorganizowania miast konurbacji górnośląskiej' (No. 1470). University of Silesia, Sosnowiec.

Tkocz, M 2005, 'La restructuration socio-économique du Bassin Industriel de Haute-Silésie', Géocarrefour, vol. 80, issue 1, pp. 49-58.

Zborowski, A 2005, 'Przemiany struktury społeczno-przestrzennej regionu miejskiego $w$ okresie realnego socjalizmu i transformacji ustrojowej (na przykładzie Krakowa)', IGiGP Jagiellonian University, Kraków.

Zborowski, A 2011, 'Changes in the Range of Influence of Medium-sized Towns in South-Eastern Poland in the Turn of the 21st Century' in Medium-sized towns of central-eastern Europe in the period of economic system transformation and social changes, ed A Runge \& A Kuczabski, Publishing House "ADNDU", Kharkiv, pp.116-133.

Zborowski, A, Soja, M \& Łobodzińska, A 2012, 'Population trends in Polish cities - stagnation, depopulation or shrinkage?', Prace Geograficzne, vol. 130, IGiGP Jagiellonian University, Kraków, pp. 7-28. DOI: 10.4467/20833113PG.12.017.0658.

Zuzańska-Żyśko, E 2003, 'Populationtypes of small towns in Silesian Province', Bulletin of Geography, Socio-economic Series, no 2, Nicolaus Copernicus University, Toruń, pp. 139-149.

Zuzańska-Żyśko, E 2005, 'Economic Transformation of Small SilesianTowns in the Year 1990-1999', in Cities in the transfoming post-communist countries: ten years of economic, social and spatial experience, ed E. Nowosielska \& J Parysek, Geographia Polonica, vol. 78, no 1, pp. 137-149, Polish Academy of Sciences, Institute of Geography and Spatial Organization, Warszawa, Poland. 